Profit: Jurnal Kajian Ekonomi dan Perbankan 2 (1) 2018. P: 87-98

PROFIT : JURNAL KAJIAN EKONOMI DAN PERBANKAN

https://ejournal.unuja.ac.id/index.php/profit

E-ISSN : 2597-9434, ISSN: 26854309

\title{
STRATEGI PENGEMBANGAN PRODUK UNTUK MENINGKATKAN DAYA SAING PRODUKSI (STUDI PADA TAPE “WANGI PRIMA RASA” DI BINAKAL BONDOWOSO)
}

Temmy Wijaya \& Ana

Maghfiroh*

- Univiversitas Nurul Jadid

Email :temmyw@gmail.com

\section{Abstract:}

Perusahaan yang sustainable adalah perusahaan yang dapat berkembang dalam berbagai produk, bertahan dan berdaya saing dengan perusahaan lainnya, termasuk pabrik Tape Prima Rasa. Penelitian ini fokus masalah pada Bagaimana proses pengembangan produk tape "Wangi Prima Rasa" dan strategi yang digunakan untuk meningkatkan daya saing di Desa Sumber Tengah Kecamatan Binakal Kabupaten Bondowoso. Penelitian ini menggunakan metode pendekatan kualitatif dengan menggunakan metode observasi, wawancara dan dokumentasi. Analisis data dalam penelitian yaitu reduksi data, penyajian data dan menarik kesimpulan. Hasil penelitian ini : strategi pengembangan produk tape "Wangi Perima Rasa" meliputi beberapa tahap dari awal sampai finishing, melalui proses pengembangan tape dengan munculnya ide, pengembangan dan pengujian konsep produk. Strategi untuk meningkatkan daya saing diantaranya produk baru bagi dunia, lini produk baru, penyempurnaan produk yang sudah ada, repositioning, pengurangan biaya.

Keyword: Development Startegy, Tape Products, Competitiveness 


\section{PENDAHULUAN}

Industri UKM pada saat ini sedang menghadapi situasi yang sedemikian rumit atau sulit di tengah perubahan lingkungan bisnis yang semakin rumit. Persainganpun sudah menjadi kian erat dan melekat dengan berjalanannya arus pergerakan perdagangan bebas yang secara otomatis membuat kompetisi datang dari segala penjuru baik domestik, regional maupun global. Dan dalam hal ini membuat tantangan tersendiri bagi para pelaku UKM di seluruh penjuru Indonesia. Namun ada peluang di balik tantangan untuk berhasil dalam usaha yang digeluti, UKM harus memiliki paradigma sebagai wirausaha sepenuhnya dan memiliki orientasi pemasaran yang mencukupi, namun juga harus sebagai pemegang pasar sesungguhnya. ${ }^{1}$

Dinamika lingkungan bisnis berdampak pada perubahan selera dan preferensi pelanggan. Perubahan ini pada gilirannya menuntut inovasi dan kreatifitas setiap organisasi agar dapat menyempurnakan produk yang sudah ada dan mengembangkan produk baru dengan menerapkan kreatifitas perusahaan untuk meningkatkan daya saing dalam mempertahankan kelangsungan hidup dan profitabilitas perusahaan. ${ }^{2}$

Konsumen akan membuat keputusan untuk membeli suatu produk apabila produk tersebut memiliki nilai lebih dibandingkan produk lainnya. Untuk membuat produk yang memiliki nilai jual dan daya saing yang tinggi, dalam proses inovasinya perusahaan harus dapat menemukan strategi bisnis yang tepat. Oleh karena itu, perusahaan perlu memanfaatkan sumber dayanya dengan optimal dan melakukan kegiatan pengembangan produk untuk menjaga keberlangsungan hidup perusahaan. Pengembangan dan desain (rancangan) produk yang baik mutunya merupakan kunci kesuksesan di dunia bisnis. ${ }^{3}$

Dengan demikian perusahaan harus berusaha membuat produk yang unggul, adapun produk unggulan perusahaan berupa produk yang lebih berkualitas, harga yang lebih murah, pembuatan pruduk yang lebih cepat, dan pelayanan yang baik dan memuaskan, sehingga konsumen lebih puas terhadap produk atau pelayanan yang diterima.

Berbicara tentang produk, usaha yang dijalankan oleh sebagian masyarakat Bondowoso yaitu memproduksi tape, karena Bondowoso terkenal dengan sebutan "Kota Tape", sehingga tape menjadi icon daerah bagi Kabupaten Bondowoso. Didukung dengan kondisi geografis dan topografis serta keahlian yang dimiliki para pengrajin, tape Bondowoso menemukan orisionalitasnya sebagai jajanan khas yang cocok untuk semua kalangan. ${ }^{4}$ Salah satu pengrajin tape yang sukses di Bondowoso adalah Tape "Wangi Prima Rasa" yang memulai usahanya sejak tahun 1997 di Desa Sumber Tengah Kec. Binakal Kab. Bondowoso. Usaha yang dijalankan oleh Tape "Wangi Prima Rasa" yaitu memproduksi tape dari singkong yang menjadi suatu makanan yang telah menjadi makanan khas di Bondowoso. tape yang dihasilkan sangat menarik perhatian masyarakat umum, apalagi para penggemar makanan. Dapat dilihat dari bagian isinya, kemasannya maupun dari rasanya. Banyak orang yang beramai-ramai untuk membeli dan memesannya. Karena produk yang ditawarkan

${ }^{1}$ Ahmad Subhan "Analisis Strategi Pengembangan Produk Keripik Singkong Di Desa Karangharjo Kecamatan Silo Kabupaten Jember", Skipsi, (Jember: Fakultas Ekonomi Dan Bisnis Islam Institut Agama Islam Negeri Jember, 2018), 1.

${ }^{2}$ Fandy Tjiptono, 'Fandy, Gregorius Chandra Dan Dedi Adriana (2008)', Pemasaran Strategik.

${ }^{3}$ Endang Sulistya Rini, 'Peran Pengembangan Produk Dalam Meningkatkan Penjualan', 2013. 
sangat cocok untuk mengisi waktu luang dan harga yang sangat terjangkau, baik untuk kalangan menengah kebawah maupun sebaliknya. Sehingga produk tape "Wangi Prima Rasa” berlomba-lomba untuk saling bersaing menawarkan produk kepada konsumen.

Persaingan yang terjadi antara usaha Tape "Wangi Prima Rasa" memunculkan strategi produk atau upaya yang harus dilakukan oleh Tape "Wangi Prima Rasa" dalam mengembangkan produknya, agar dapat bersaing dengan produk Tape " 85 ” yang juga berada di satu desa atau wilayah dengan Tape "Wangi Prima Rasa". Maka strategi produk yang dilakukan sebagai upaya mempartahakan produknya agar tetap menarik perhatian pelanggan. Oleh karena itu, peneliti tertarik untuk meneliti produk tape "Wangi Prima Rasa" karena produk tersebut memiliki ciri khas dalam rasanya, serta pemasarannya yang sudah cukup luas jangkauannya.

Dalam hal menawarkan atau memasarkan produk Tape "Wangi Prima Rasa", berbagai macam cara unik atau menarik yang dilakukan. Baik dari segi isi, merk maupun kemasan yang mereka buat semenarik mungkin untuk memikat hati konsumen. Tape "Wangi Prima Rasa” dalam mengembangkan produknya dapat dikatakan cukup baik. Karena dapat dilihat dari pesanan pelanggan yang semakin meningkat dan munculnya pesaing baru untuk menyaingi usaha mereka, yaitu dengan mengelola beberapa olahan menjadi bervariasi diantaranya tape bakar, prol tape, suwar-suwir, dan lain lain. Hal menarik lain dari Tape "Wangi prima Rasa" adalah produk yang mereka tawarkan, segmentasi pasarnya yang cukup luas jangkauannya sehingga dapat dijangkau oleh masyarakat luas, baik dari kalangan ekonomi bawah, menengah dan atas. Dalam hal jumlah volume pemesanan mereka tidak pilih-pilih, artinya baik pesanan sedikit maupun banyak dan dekat ataupun jauh mereka tetap menerima pesanan tersebut, sehingga pelanggan merasa puas dengan produk yang ia beli.

Dalam hal ini, peneliti sangat tertarik untuk meneliti cara mengembangkan produk dan membuat konsumen memiliki sikap loyalitas yang tinggi, karna dilihat dari banyaknya pesaing produk tape di desa Sumber Tengah Kecamatan Binakal Kabupaten Bondowoso, terdapat salah satu produk saingan yaitu tape "85". Produk ini tidak memiliki variasi rasa dalam pemasarannya dan bertempat di satu wilayah dengan produk tape "Wangi Prima Rasa". Sehingga tape "Wangi Prima Rasa" harus merancang strategi pemasaran dengan produk unggulan yang bervariasi rasa produknya sehingga bisa membuat konsumen berlangganan dan meninggatkan daya saingnya.

\section{TEORI}

Strategi dirancang untuk memastikan tujuan utama perusahaan bisa diperoleh melalui pelaksanaan yang tepat dan juga merupakan rencana yang disatukan secara menyeluruh dan terpadu guna mengaitkan keunggulaan strategi perusahaan. ${ }^{5}$ Pengembangan produk merupakan suatu kegiatan atau aktivitas yang dijalankan dalam menghadapi yang berkemungkinan akan merubah sebuah produk ke arah yang lebih baik agar bisa memberikan manfaat maupun kepuasan yang lebih tinggi. ${ }^{6}$ Karna produksi merupakan suatu hal yang primer dalam kehidupan. ${ }^{7}$ Pengembangan produk bisa dijalankan oleh personalia dalam perusahaan dengan sistem mengembangkan produk baru

${ }^{5}$ Assauri Sofjan, 'Manajemen Pemasaran Dasar, Konsep Dan Strategi', Jakarta: Penerbit PT Rajagrafindo Persada, 2010.

${ }^{6}$ Sofjan.

${ }^{7}$ Moh Idril Gufron, ‘Peningkatan Produksi Dalam Sistem Ekonomi Islam Sebagai Upaya Pemberdayaan Ekonomi Umat', Dinar Jurnal Ekonomi Dan Keuangan Islam, 2.1 (2015).

89 Profit : Jurnal Kajian Ekonomi dan Perbankan 
dengan menyesuaikan model- model yang sesuai. ${ }^{8}$ Ada beberapa cara yang dapat perusahaan lakukan dalam pengembangan produk yaitu:

1. Penciptaan ide

Pengembangan produk baru diawali dengan penciptakan ide yang merupakan pencarian sistematis untuk ide produk yang baru. pengusaha kadang kalanya mempunyai beberapa ide baru untuk dapat mendapatkan sedikit ide yang baik. Tujuan dari penciptaan ide ini adalah menghasilkan ide yang cukup banyak. ${ }^{9}$ Ide baru ini harus dipertimbangkan apakah ide ini flexible atau layak untuk diproses, jika ide ini layak maka diteruskan tapi jika tidak maka dihentikan $(d r o p) .{ }^{10}$

2. Penyaringan ide

Tujuan penyaringan ide adalah menemukan ide dalam jumlah yang tidak sedikit. maksud dari tahapan ini yaitu menurunkan jumlah tersebut. Tahap pertama dalam proses pengurangan ide adalah penyaringan ide (idea screening), yaitu menemukan ide untuk menciptakan ide yang baik dan menyingkrkan ide yang kurang baik. Dalam hal ini produsen bisa menghasilak ide-ide baik yang sesuai dengan kebutuhan konsumen.

3. Pengembangan dan pengujian konsep

Setelah ide disaring dilakukan langkah selanjutnya adalah memperkenalkan model produk baru kemudian diperlihatkan kepada konsumen, dan mengadakan suvei terhadap pendapat konsumen pada produk baru tersebut.

4. Pengembangan strategi pemasaran

Dalam ini perusahaan merencanakan strategi pemasaran produk baru dengan menggunakan segmentasi pasar tertentu, serta cara informasi yang digunakan.

5. Analisis usaha

Analisis usaha dilakukan dengan cara memperbaiki jumlah penjualan dibandingkan dengan pembelian bahan baku, biaya produksi dan perkiraan laba.

6. Pengembangan produk

Dalam pengembangan produk ini gagasan produk yang masih dalam rancangan dikirim pada bagian produksi untuk dibuat, menaruh merk, dan membuat kemasan yang dengan semenarik mungkin. Dan inti merk yang berhasil adalah produk atau jasa yangunggul yang didukung oleh perencanaan yang sama, sejumlah besar komitmen dalam jangka panjang, dan pemasaran yang

${ }^{8}$ Buchari Alma, 'Manajemen Pemasaran Dan Pemasaran Jasa', Bandung: Alfabeta, 2007.

${ }^{9}$ Alma.

${ }^{10}$ Fajar Laksana, 'Manajemen Pemasaran Pendekatan Praktis', Yogyakarta: Graha Ilmu, 2008. 
diatur dan dijalankan secara kreatif dan baik. Merk yang kuat akan menghasilakan pelanggan yang yang berlangganan.

\section{Market testing}

Langkah selanjutnya produk baru dipasarkan di segmen yang sudah dirancang sejak awal, maka dari itu akan diperoleh informasi yang sangat penting tentang keadaan barang, agen, permintaan potensial, dan sebagainya.

\section{Komersialisasi}

Setelah perencanaan matang, dilaksanakan, dan diuji, maka memproduksi dengan skala besar yang memerlukan modal investasi yang cukup besar. Mulailah menciptakan produk baru di pasar, yang akan menjalani proses kehidupan sebagai suatu produk baru, sampai kepada tahap proses adopsi oleh pihak konsumen, maka mampu menyebabkan kepuasan bagi pelanggan, dan mengaut keuntungan bagi perusahaan.

Pesaing adalah perusahaan yang meluncurkan atau menjual barang atau jasa yang sama atau mirip dengan produk yang kita tawarkan. Pesaing suatu perusahaan dapat diketagorikan menjadi dua, yaitu pesaing yang kuat dan pesaing yang lemah. ${ }^{11}$ Memahami konsumen saja tidak cukup bagi manajer pemasaran untuk masa sekarang. Bisnis-bisnis harus bekerja lebih keras untuk merebut pasar. Akibatnya bisnisbisnis tersebut juga mulai memperhatikan para pesaingnya di samping tetap berusaha memahami konsumen.. Maka Analisis pesaing sangat diperlukan bagi efektifitas pemasaran. Karena dari perkembangan dunia industri semakin pesat, beraneka ragam usaha dibuka dengan leluasa. ${ }^{12}$

Pengembangan produk harus dibuat agar dapat mempertahankan dan meningkatkan Daya saing. Pengembangan produk merupakan salah satu langkah perusahaan agar dapat tetap bertahan dan mengembangkan produk untuk dapat meningkatkan daya saing perusahaan. Halhal yang termasuk di dalam pengembangan produk adalah penentuan kualitas, ukuran, bentuk, daya tarik, labeling, cap tanda (branding), pembungkus (packaging), dan sebagainya untuk menyesuaikan selera yang sedang tumbuh. Aktifitas pengembangan produk baru bisa menciptakan daya saing ada 6 macam tipe produk yaitu: ${ }^{13}$

1. Produk barubagi dunia

Menurut Teori Michel Porther salah satu hal yang mengacu dari daya saing adalah factor conditions. Kunci utama faktor produksi "diciptakan" inovasi produk baru sebagai hasil inovasi yang menghasilkan segmentasi atau pangsa pasar yang baru yang bisa membuat perusahaan

\footnotetext{
${ }^{11}$ Kasmir, kewirausahaan, 279.

${ }^{12}$ Moh Idil Ghufron and Inas Fahmiyah, 'KONSEP WARALABA PERSPEKTIF EKONOMI ISLAM', Amwaluna: Jurnal Ekonomi Dan Keuangan Syariah, 3.1 (2018).

${ }^{13}$ Tjiptono. 
berdaya saing dengan produk lain. Produk baru yang diciptakan harus memiliki tempat atau pasar yang baru agar dikenal oleh konsumen

2. Lini produk baru

Menurut Teori Michel Porther dalam pembedaan produk (differentiation). Salah satu hal yang dapat mengacu dari daya saing yaitu menemukan keunikan tersendiri misalnya menemukan produk baru atau mengembangkan produk dalam pasar yang menjadi sasaran, yang bisa memungkinkan perusahaan untuk memasuki pasar yang sebelumnnya telah ada untuk pertama kali dan untuk berlomba juga bersaing dengan produk lain.

Bagi perusahaan merupakan produk baru namun bagi konsumen bukan termasuk baru lagi karena sebelumnya sudah ada produk yang sama yang masuk terlebih dahulu di pasar itu disebut dengan lini produk baru. Sering kali pesaing dalam melakukan inovasi produknya kadangkadang muncul dari adanya usaha baru, seperti memproduksi barang baru atau juga bisa dengan meniru produk yang sudah ada dengan cara memodifikasi ulang produk tersebut.

3. Penyempurnaan produk yang sudah ada

Menurut teori Michel Porther dalam strategi focus untuk meningkatkan daya saing perusahaan yang berkonsentrasi dalam produk perusahaan sendiri atau dengan memperbaiki produk perusahaan dengan inovasi yang baru yang telah disempurnakan untuk mengganti produk lama upaya meningkatkan penjualan dan bersaing di pasaran. Ada beberapa hal yang bisa dilakukan perusahaan agar dapat mempertahankan produknya di pasarInovasi produk, ialah menginovasi produk jasa atau kombinasi keduanya yang baru

4. Repositioning

Menurut teori Muhardi daya saing operasi merupakan fungsi operasi yang tidak hanya memproduksi ke dalam (internal) tetapi juga keluar (eksternal). Maka pengembangan teknis yang memungkinkan suatu produk menawarkan produk baru atau produk yang sudah adsa yang baru dipasarkan sehingga dapat memperluas pesaing pemasarannya. Sasaran pesaing antara lain:
a. Memaksimalkan laba
b. Memperbesar market share
c. Meningkatkan mutu produk
d. Mematikan atau menghambat pesaing lainnya.

5. Penguragan biaya

Menurut Michel Porther jika perusahaan ingin meningkatkan daya saing usahanya dalam persaingan yang ketat perusahaan harus memiliki prinsip bisnis dengan harga yang tinggi dengan 
biaya produk yang rendah yang diharapkan mendapatkan laba yang tinggi dan membuat konsumen tetap menjadi pelanggan. Hal-hal yang harus dipertimbangkan dalam proses pengurangan biaya adalah harga ditetapkan berdasarkan perhitungan besarnya biaya yang dibutuhkan (biaya bakan baku, harga pokok produksi, dan biaya promosi)

a. Harga yang ditetapkan berdasarkan perhitungan besarnya biaya yang dibutuhkan ditambahkan dengan persentase keuntungan yang diinginkan

b. Harga adalah nilai suatu barang atau jasa yang diukur dengan sejumlah uang demi mendapatkan sebuah barang atau jasa yang diinginkan. Bagi pelanggan yang sensitif biasanya harga yang murah adalah sumber kepuasan yang sangat penting karena akan mendapatkan value for money yang tinggi.

Dalam lingkungan persaingan yang semakin ketat dan juga didukung oleh letak pasar yang dinamis, maka setiap perusahaan tidak bisa menghindari adanya persaingan. Hal yang harus diperhatikan penuh adalah menghadapi tingkat persaingan tersebut dengan cara sebaikbaiknya. Maksudnya disini dapat tarik sebagai upaya yang dilakukan secara optimal dan berkesinambungan untuk menghasilkan sesuatu yang lebih baik saat ini dan di masa yang akan dating.

Jadi pengembangan produk yang ditawarkan untuk meningkatkan daya saing di masyarakat yaitu memproduksi sebuah produk baru agar perkembangan perusahaan tersebut semakin meningkat dan dapat bertahan dalam menyambut persaingan dengan perusahaan lain. Ada 5 cara yang digunakan dalam mengembangkan produk untuk meningkatkan daya saing diantaranya: produk baru bagi dunia, lini produk baru, perluasan lini, penyempurnaan produk yang sudah ada, repositioning, dan pengurangan biaya.

\section{METODE PENELIIAN}

Penelitian ini dikategorikan sebagai penelitian interpretif dan naturalistik yaitu penelitian terhadap pokok persoalannya, berusaha memahami atau menginterpretasi fenomena dalam hal makna makna yang orang orang berikan pada fenomena tersebut. Sedangkan jenis penelitiannya adalah studi kasus. Dalam hal ini peneliti mencoba untuk memahami bagaimana cara memgembangkan produk tape "Wangi Prima Rasa". Selain itu peneliti juga mencoba untuk menggali tentang bagaimana cara tape "Wangi Prima Rasa" untuk meningkatkan daya saingnya. 
Serta apa saja yang dilakukan perusahaan untuk mempertahankan produk dan loyalitas konsumen. ${ }^{14}$

\section{HASIL PENELITIAN}

Produk tape “Wangi Prima Rasa" merupakan perusahaan yang bergerak dalam industri konsumsi yang mempruduksi bahan baku menjadi bahan jadi, yaitu olahan tape. Dalam setiap produksi ini pastinya ingin mendapatkan laba yang besar dan konsumen yang loyal. Oleh karena itu perusahaan ini melakukan beberapa strategi inovasi diantaranya rasa, model dan bentuknya. Gambar Siklus kehidupan produk tape "Wangi Prima Rasa" bila dibandingkan dengan perusahaan lain yang tanpa memakai strategi produk baru atau variasi rasa.

Tabel 1.1 Siklus kehidupan produk Tape "Wangi Prima Rasa”

\begin{tabular}{|r|c|c|c|}
\hline No & $\begin{array}{c}\text { Nama } \\
\text { produk }\end{array}$ & Tahun & Bahan dasar tape \\
\hline 01 & Tape Biasa & $1997-1999$ & $20 \mathrm{~kg}-1 \mathrm{kw}$ \\
\hline & & $2000-2005$ & $2 \mathrm{kw}-4 \mathrm{kw}$ \\
\hline & & $2006-2016$ & $3 \mathrm{kw}-4 \mathrm{kw}$ \\
\hline & & $2017-2018$ & $4 \mathrm{kw}-5 \mathrm{kw}$ \\
\hline 02 & Tape bakar & 2000 & $50 \mathrm{~kg}-2 \mathrm{kw}$ \\
\hline & & $2001-2008$ & $3 \mathrm{kw}-5 \mathrm{kw}$ \\
\hline & & $2009-2015$ & $5 \mathrm{kw}-6 \mathrm{kw}$ \\
\hline 03 & Prol Tape & $2016-2018$ & $6 \mathrm{kw}-7 \mathrm{kw}$ \\
\hline & & 2000 & $50-2 \mathrm{kw}$ \\
\hline & & $2001-2008$ & $2 \mathrm{kw}-3 \mathrm{kw}$ \\
\hline & & $2016-2018$ & $3 \mathrm{kw}-4 \mathrm{kw}$ \\
\hline & Suwar Suwir & 2000 & $4 \mathrm{kw}-5 \mathrm{kw}$ \\
\hline & & $2001-2008$ & $2 \mathrm{~kg}-1 \mathrm{kw}$ \\
\hline & & $2009-2015$ & $3 \mathrm{kw}-4 \mathrm{kw}$ \\
\hline & & $2016-2018$ & $1 \mathrm{kw}$ \\
\hline
\end{tabular}

Table 1.3 Siklus Kehidupan Produk Tape "85"

\begin{tabular}{|c|c|c|c|}
\hline No & $\begin{array}{c}\text { Nama } \\
\text { Produk }\end{array}$ & Tahun & Bahan dasar tape \\
\hline
\end{tabular}

${ }^{14}$ Suharsimi Arikunto, Prosedur Penelitian: Suatu Pendekatan Praktik (Rineka cipta, 1992).

94 Profit : Jurnal Kajian Ekonomi dan Perbankan 


\begin{tabular}{|c|c|c|c|}
\hline 01 & Tape Biasa & 2016 & $2 \mathrm{kw}-3 \mathrm{kw}$ \\
\hline & & 2017 & $3 \mathrm{kw}-4 \mathrm{kw}$ \\
\hline & & 2018 & $3 \mathrm{kw}-4 \mathrm{kw}$ \\
\hline
\end{tabular}

Dari tabel di atas dapat dijelaskan bahwa perusahaan tape "Wangi Prima Rasa” terus menciptakan ide-ide baru, sehingga dalam setiap tahunnya terjadi kenaikan perkembangan produk seperti yang akan peneliti jelaskan secara rinci berikut ini. Untuk olahan singkong menjadi tape biasa rincian perkembangannya adalah sebagai berikut: pada tahun 1997-1999 tape "Wangi Prima Rasa” memproduksi 20 kg-1 kwintal. Kemudian pada tahun 2000-2005 tape “Wangi Prima Rasa” memproduksi singkong sebanyak 2-4 kwintal, dilanjutkan ke tahun 2006-2016 memproduksi 3-4 kwintal. Pada tahun 2017-2018 dapat memproduksi singkong menjadi olahan tape sebanyak 4-5 kwintal.

Kemudian untuk olahan tape bakar rincian perkembangannya dari tahun ke tahun adalah sebagai berikut: pada tahun 2000 proses produksinya membutuhkan $50 \mathrm{~kg}-2$ kwintal bahan dasar singkong. Pada tahun 2001-2008 membutuhkan 3-5 kwintal singkong. Kemudian pada tahun 20092015 membutuhkan 5-6 kwintal singkong, dilanjutkan pada tahun 2016-2018 membutuhkan 6-7 kwintal singkong untuk dijadikan olahan tape bakar. Selanjutnya pada pengolahan prol tape rinciannya adalah sebagai berikut: pada tahun 2000 membutuhkan $50 \mathrm{~kg}-2$ kwintal. Tahun 20012008 dibutuhkan singkong sebanyak 2-3 kwintal. Pada tahun 2009-2015 membutuhkan 3-4 kwintal, dilanjutkan pada tahun 2016-2018 membutuhkan 4-5 kwintal.

Untuk olahan tape dalam varian jenis suwar-suwir bentuk rinciannya adalah sebagai berikut: pada tahun 2000 dibutuhkan 50 kg-1 kwintal singkong. Tahun 2001-2008 bisa membutuhkan 2-3 kwintal. Sedangkan untuk tahun 2009-2015 dibutuhkan 3-4 kwintal singkong, dilanjutkan pada tahun 206-2018 membutuhkan 5 kwintal singkong untuk bahan dasar pembuatan tape dalam varian jenis suwar-suwir. Jadi, dapat disimpulkan bahwa tape bakar merupakan varian jenis yang paling banyak membutuhkan singkong untuk bahan dasar olahannya.

Kemudian peneliti juga melakukan observasi pada usaha tape dengan merk berbeda yaitu tape "85" berikut rincian dari hasil observasi peneliti. Pada tahun 2016 tape "85" membutuhkan 2-3 kwintal singkong. Tahun 2017 dan 2018 membutuhkan 3-4 kwintal. Kemudian pada tahun 2018 dibutuhkan 4-5 kwintal. Jadi dari analisis di atas tape "wangi prima rasa" lebih banyak memproduksi dan berdaya saing dari pada perusahaan tape lain yang hanya menjual tape biasa. Dikarenakan perusahaan tape "Wangi Prima Rasa" memiliki beberapa jenis olahan tape dan varian rasa yang yang berbeda-beda. Tape "Wngi Prima Rasa" juga melakukan strategi dengan cara mempromosikan produk tersebut di berbagai daerah sekitar Bondowoso. Sehingga perusahaan tersebut mudah menarik minat konsumen.

Suatu tantangan paling besar yang dihadapi perusahaan adalah masalah pengembangan produk. Pengembangan produk dapat dilakukan oleh personalia dalam perusahaan dengan cara mengembangkan produk yang baru dengan menyesuaikan model- model yang sesuai. ${ }^{15}$ Pengembangan produk merupakan kegiatan atau aktivitas yang dilakukan dalam menghadapi

\footnotetext{
\begin{tabular}{l|l}
\multicolumn{2}{c}{ Alma. } \\
\hline 95 & Profit : Jurnal Kajian Ekonomi dan Perbankan
\end{tabular}
} 
kemungkinan perubahan suatu produk ke arah yang lebih baik sehingga dapat memberikan daya guna maupun daya saing yang lebih besar. ${ }^{16}$ Pengembangan produk harus dibuat agar dapat mempertahankan dan meningkatkan Daya saing.

Sebelum terbentuk sebuah olahan tape yang beraneka ragam, awal produksinya dengan model olahan tape biasa dan pemasarannya di sekitar desa tersebut. Seiring berjalannya waktu usaha tersebut berkembang begitu pesat menjadi olahan tape bakar yang beraneka rasa dan pemasarannya meluas hingga ke daerah Kota Bondowoso dengan kualitas yang terjamin. Hingga akhirnya usaha meluas samapai ke daerah di luar kabupaten. Untuk menjaga kualitas dan segmentasi pasar maka dibuatkan legalitas dengan mengurus ijin usaha ke Dinas Perdagangan Kabupaten, di beri nama perusahaan tape "wangi prima rasa". Dalam menghadapi tantangan para pesaing yang semakin ketat ini, perusahaan tape "Wangi Prima Rasa" mempunyai beberapa cara ampuh untuk tetep memasarkan produk tersebut agar tetap laku dipasaran dengan kualitas yang lebih baik dari sebelumnya, sehingga minat konsumen tetap terjaga dengan baik.

Salah satu cara yang dipilih oleh perusahaan tape "Wangi Prima Rasa” untuk mengimbangi ketatnya persaingan di luar adalah memiliki beberapa jenis olahan tape, yang besar kemungkinan bisa diterima baik oleh konsumen dengan varian-varian baru dari perusahaan tersebut seperti: tape biasa, tape bakar, dodol tape, dan suwar-suwir. Pengembangan produk baru dimulai dengan penciptaan ide yang sistematis untuk ide produk baru. Jenis pertama yang dipilih adalah olahan tape bakar yang memang perusahaan tersebut memilik cara sendiri untuk membakar tape tersebut dengan menggunakan areng pilihan yang memang di jual didaerah Bondowoso. Sehingga kematangan yang dimiliki sangat pas, tidak terlalu matang ataupun kurang matang.

Dari tape bakar ini pun muncul ide baru yang bisa dikembangkan lagi yaitu dengan menawarkan varian rasa yang cukup banyak untuk menyesuaikan minat konsumen sesuai selera. Rasa yang dipilih di setiap satu bumgkus itu bermacacam-macam ada rasa cokelat, srowberry, gula jawa, dan nanas. Dalam satu bungkus itu terdapat beberapa macam rasa, atau bisa disesuaikan selera para konsumen

Kemudian selang beberapa waktu perusahaan tape Wangi Prima Rasa memunculkan ide baru dengan memuncukan produk lama yaitu suwar-suwir yang biasanya di kenal di Daerah Jember saja, namun perusahaan tape "Wangi Prima Rasa" memilih memodifikasi ulang produk suwar-suwir menjadi lebih unik dan memiliki kesan tersendiri di hati para konsumen. Bentuk yang dipilih oleh perusahaan tape "Wangi Prima Rasa" ialah dengan memotong kecil-kecil seukuran dodol dan yang lebih menonjol ketidak samaannya dengan produk yang ada di Jember ialah swar-swir yang berlapis seperti kue lapis.

Seiring waktu, dari hasil menciptakan beberapa jenis tape dan memodivikasi ulang olahan tape, perusahaan tape "Wangi Prima Rasa" semakin dikenal oleh masyarakat sekitar dan penghasilan yang dimilik semakin berkembang pesat. Hingga pada akhirnya muncullah ide baru dengan menciptakan jenis baru dari olahan tape yaitu dodol tape dan saat ini menjadi ciri khas dari kota Bondowoso.

\section{PENUTUP}

${ }^{16}$ Sofjan Assauri, Manajemen Pemasaran: Dasar, Konsep Den Strategi (CV Rajawali, 1987). 
Produk tape "Wangi Prima Rasa" dalam mengembangkan produknya yaitu dengan meliputi beberapa tahap yaitu pengembangan ide dan pengujian produk serta pengembangan strategi pemasaran produk. Setelah dipasarkan kemudian dianalisis usahanya dengan market testing, dan terakhir komersialisasi atau memproduksi produk dengan skala yang besar.

Untuk meningkatkan daya saing, tape "Wangi Prima Rasa" mengembangkan produknya dengan model varian-varian baru Adapun produk baru yang dimiliki oleh tape "wangi prima rasa" adalah tape bakar, prol tape, dan suwar-suwir. 


\section{DAFTAR PUSTAKA}

Alma, B. 2016. Manajemen Pemasaran dan Pemasaran Jasa. Bandung: Alfabeta.

Arikonto, S. 2002. Prosedur Penelitian Suatu Pendekatan Praktek. Jakarta: Rineka Cipta.

Assauri, S. 2011. Manajemen Pemasaran, Dasar Konsep dan Strategi. Jakarta: Rajawali Pers.

Ghofron, I.(2015) peningkatan produksi dalam sistem ekonomi islam sebagai upaya pemberdayaan ekonomi umat (Dinar, 1 (02). 01.

Ghofron, I. Dkk, 2018 Konsep Waralaba Perspektif Ekonomi, (Amwaluna 3(01). 01.

Kasmir. 2013. Kewirausahaan. Jakarta: Rajawali Pers.

Laksana, F. 2008. Manajemen Pemasaran Pendekatan Praktis. Yogyakarta: Graha Ilmu.

Muhadjir, N. 2000. Metodologi Penelitian Kualitatif. Yogyakarta: Rake Sarasin.

Noor, J. 2002. Metodologi Penelitian: Skripsi, Tesis, Disertasi, dan Karya Ilmiah. Jakarta: Prenada Media Group.

Rini, E. 2013. Peran Pengembangan Produk dalam Meningkatkan Penjualan. Jurnal Ekonomi.

Subhan, A. 2018. Analisis Strategi Pengembangan Produk Keripik Singkong Di Desa Karangharjo Kecamatan Silo Kabupaten Jember. Skripsi.

Sugiyono. 2008. Metode Penelitian Kuantitatif, Kualitatif dan R\&D. Bandung: Alfabeta.

Saputra, U. 2012. Metode Penelitian Kualitatif, Kuantitatif, dan Tindakan. Bandung: Refika Aditama.

Tjiptono, F Dkk. 2008. Pemasaran Strategik. Yogyakarta: CV. Andi Offset.

Purwanto, I. 2002. Manajemen Strategi. Bandung: Yrama Widya. 